\title{
Öğrenciler Arasında Blokzincir Farkındalığı Üzerine Bir Araştırma
}

\author{
Şerif Bahtiyar*, Oğuz Paksoy, Ecem Güldöşüren, Mustafa Efekan Pekel \\ İstanbul Teknik Üniversitesi, Bilgisayar ve Bilişim Fakültesi, Bilgisayar Mühendisliği Bölümü, İstanbul, Türkiye
}

(İlk Geliş Tarihi 28 Ocak 2020 ve Kabul Tarihi 5 Mart 2020)

(DOI: $10.31590 /$ ejosat.681021)

ATIF/REFERENCE: Bahtiyar, Ş., Paksoy, O., Güldöşüren, E. \& Pekel, M. E. (2020). Öğrenciler Arasında Blokzincir Farkındalığı Üzerine Bir Araştırma. Avrupa Bilim ve Teknoloji Dergisi, (18), 424-434.

\begin{abstract}
Öz
Moderen toplumlar gün geçtikçe daha çok teknoloji ile iç içe yaşar hale gelmeye başlamıştır. Aynı zamanda toplumlar arası rekabet geleneksel savaş veya ekonomik alanlarından teknolojik alanlara doğru yönelmeye başlamıştır. Bu durum, toplumların teknolojiyi geliştirecek daha çok insan gücüne ihtiyaç duymasına sebep olmaktadır. Blokzincir teknolojisi gelişmekte olan hesaplama biliminin birçok alanı için yenilikçi çözümler sunduğundan gittikçe artan sayıda araştırmacı ve insanın ilgisini çekmektedir. Bununla birlikte, blokzincir teknolojisi ile ilgili araştırma ve geliştirmedeki olağanüstü sorunların çözülebilmesi için iyi eğitimli araştırmacılara ve geliştiricilere ihtiyaç vardır. Aksi durumda bu teknoloji, aldatıcı bir reklemın ötesine geçemeyecektir. Bu çalışamızda, blokzinciri teknolojisine katkıda bulunabilecek en iyi adaylar arasında yer alan üniversite öğrencilerinin blokzinciri teknolojisi farkındalığını değerlendirmeye odaklandık. Üniversite öğrencileri arasındaki blokzinciri farkındalığını belirlemek için yeni bir anket araştırması gerçekleştirdik. Anketi çevrimiçi bir uygulama kullanarak 200 öğrenci ile deneysel olarak gerçekleştirdik. Gerçekleştirdiğimiz analizler, üniversite öğrencilerinin blokzincir teknolojisine katkıda bulunmaya hevesli olduklarını ve bu teknoloji ile yeni uygulamalar geliştirmek istediklerini göstermektedir. Diğer taraftan, yaptığımız analizlerin sonuçları, öğrencilerin blokzincir teknolojisi araştırma topluluğuna katılmalarının önünde bazı engeller olduğunu da ortaya koymaktadır. Temel engellerden biri, blokzincir teknolojisi ve uygulamaları ile ilgili yeterli eğitim ve öğretim programlarının olmaması olarak ortaya çıkmıştır. Var olan programların da günümüz teknolojik alt yapısı gözetilmeden geleneksel yöntemler kullandığını ortaya koymaktadır. Oysa şu andaki üniversite öğrencileri daha çok görsel materiel içeren, yazının daha az olduğu etkileşimli eğitim programlarını tercih ettiğini ortaya koymaktadır. Yaptığımız bu çalışmadan elde ettiğimiz sonuçlar kullanılarak blokzincir teknolojisinin olgunlaşması için geliştirilecek eğitim programlarının yararlanmasını beklenmektedir. Özellikle üniversite seviyesindeki eğitimler için tasarlanacak blokzincir teknolojisi programlarının çalışmamızın sonuçlarının yararlı olması beklenmektedir.
\end{abstract}

Anahtar Kelimeler: Blokzincir, Farkındalık, Kriptografi, Araştırma.

\section{A Survey on Blockchain Awareness among Students}

\begin{abstract}
Modern societies are beginning to become more and more intertwined with technology. At the same time, inter-communal competition has begun to move from traditional war or economic fields to technological fields. This circumstance reveals that societies need more work force to develop technology. There has been a growing interest in blockchain since it is considered as an emerging revolutionary technology for many areas of computing. However, outstanding problems in blockchain research and development must be solved to go beyond the hype that require well-educated researchers and developers. This paper focuses on assessing the blockchain awareness of university students who are among the best candidates to contribute the technology. We presented a new survey to explore the blockchain awareness among university students. We experimentally evaluated the survey with two hundred students by using an online questionnaire. Analyses results show that university students are willing to contribute on blockchain technology and they want to develop new applications with that technology. On the other hand, these results also reveal that there are some obstacles for students to participate in the blockchain research community. One of main obstacles is a lack of sufficient training and education programs related
\end{abstract}

\footnotetext{
* Sorumlu Yazar: İstanbul Teknik Üniversitesi, Bilgisayar ve Bilişim Fakültesi, Bilgisayar Mühendisliği Bölümü, İstanbul, Türkiye ORCID: 00000003-0314-2621, bahtiyars@itu.edu.tr
} 
to blockchain technology and its applications. Specifically, existing programs use traditional methods regardless of contemporary technological infrastructure. However, our research reveals that current university students prefer interactive education programs that contain more visual materials and less writing. The results of this survey are expected to be used to create such programs. We particularly expect that the results of our research will become useful for blockchain technology programs designed especially for university level.

Keywords: Blockchain, Awareness, Cryptography, Survey.

\section{Introduction}

In recent years, advancements in new technologies have resulted in the emergence of new services and applications in our society such as blockchain-based electronic healthcare record system for healthcare 4.0 applications (Tanwar, S., et al., 2020). Another example is Internet of Things (IoT) that has introduced smart services in industry (Dai, H., et al., 2019). However, these technologies confront various challenges, like security and privacy challenges, due to luck of awareness among many peaple who may be either developer or simple application users (Mishra, M., 2018; Henry, C. Et al, 2019).

Blockchain has certainly left its mark on the society. The decentralized nature of blockchain makes it an important candidate for software solutions, such as e-voting, distributed and tax-free banking, secure decentralized data storage, digital currency, and many services on IoT devices. On the other hand, the potential of blockchain has yet to be depleted. For instance, location based services tend to use blockchain technology. However, blockchain based applications and services are vulnerable to many attacs (Nosouhi, M., et al., 2020), such as location spoofing attacks by dishonest users who misrepresents their location and submit fake position data (Zheng, Y., et al., 2017).

Altough blockchain technology has many application areas, some people often believe that blockchain is a technology only for cryptocurrency applications. This creates an implicit problem, as the public attitude towards blockchain becomes directed towards certain applications that prevents pervasive usage of blockchain with different applications. Specifically, blockchain is made popular by the introduction of a new type cryptocurrency, bitcoin (Aggarwal, S., et al., 2019). A fundamental requirement of bitcoin is to avoid double spending without involving any centralized authority. Blockchain technology provides a trusted network where the nodes are anonymous and each node has its own ledger to store the history of the transactions to ensure trust (Lo, S. K.,et al., 2017; Aste, T., et al., 2017).

The grand challenge is to increase the awareness of researchers and developers about blockchain technology, which makes the society to benefit from blockchain considerably. The first stage of increasing awareness is to determine status of potential researchers and developers. University students are among the best candidates to contribute developing blockchain applications. In this paper, the challenge is to determine blockchain awareness among university students. We design a novel online questionnaire for university student to reveal blockchain awareness among them. We have conducted an experiment 200 university students. The main contribution of this paper is the online questionnaire specifically designed for university students related to blockchain technology. Our experimental results show that students are willing to contribute on blockchain technology however, there is a lack of formal training and education programs. The results may be used to create training and education programs related to blockchain according to preferred study channels of students.

The rest of the paper is organized as follows. Section 2 is about blockchain and related research. We present our questionnaire in Section 3. Next section is devoted to research and development challenges about blockchain. We conclude the paper in Section 5.

\section{Blockchain and Research}

Surveys related to blockchain have been generally conducted by industry according to different dimensions of the technology. A survey conducted in India among 100 participants reveal that $41 \%$ of people have heard about blockchain as a cryptocurrency and $78 \%$ of them believe that cryptocurrencies can be useful for purchases. However, only 28\% of people have trust to cryptocurrencies (Mishra, M., 2018).

Another survey which was carried out by Bank of Canada with 1997 participants that illustrates the blockchain awareness of people, where older and less educated people are unaware about blockchain (Henry, C., et al., 2019).

A consulting company, Deloitte, performed a study with 1053 participants from different countries, where $84 \%$ of participants thought that block-chain technology can be highly scalable and it will be a mainstream technology in the future. In addition, $59 \%$ of participants thought that blockchain technology has damaging effects. On the other hand, 84\% of participants stated that Bitcoin-based solutions are safer and more reliable than traditional solutions (Pawczuk, L., et al., 2018).

In a research performed by MBN Solutions, a blockchain consulting company, $64 \%$ of company managers considered blockchain to be a reliable technology platform (Deloitte's., 2018).

While these surveys do not provide in-depth information about the awareness of developers who have been created applications with blockchain. Our survey considers engineering students who have a very big potential to create cutting-edge applications with blockchain technology. 


\subsection{Basics of Blockchain}

Understanding the principles of blockchain will reveal many key issues behind questions in our questionnaire. The blockchain technology was introduced in Bitcoin paper of Satoshi Nakamoto (Nakamoto, S., 2008). It is unclear whether Nakamoto ever existed (Di Pierro, M., 2017), but the concept that was explained has revolutionized distributed applications. Since then, the term "blockchain" has become a popular word in distributed technology. The power of blockchain has become apparent with its advantages on distributed systems. Blockchain has the following main benefits:

- Transparency: Peers can see what other peers are doing on the blockchain (Aste, T., et al.,.2017).

- Trustless: Peers do not need to trust any central mediator party (Aste, T., et al.,.2017).

- Attack resistance: Require immense computation power to tamper the system for PoW like consensus mechanisms (Cai, W., et al., 2018, Aste, T., et al.,.2017).

- Autonomous: The blockchain system works autonomously (Aste, T., et al.,.2017).

- Defect Traceability: Defective points on the blockchain may be detected.

- Pseudo anonymity: Participating peers can hide their real identity for Bitcoin like blockchains (Nakamoto, S., 2008, ).

- Smart contract: It is a computerized transaction protocol that executes the contractual terms of an agreement (Dai, H., et al., 2019).

Blockchain technology, in its essence, is a way of ensuring that a group of digital peers can cooperate through a network that consists of many peers, using digital signatures and hashes to provide integrity and non-repudiation. Digital signatures are used to digitally verify identities of peers (Roy, A. and Karforma, S., 2012), while a hash is a mathematical function, which is not plausibly, inverted (Yaksic, V. O. C., 2003). The reliability of the blockchain network depends on these cryptographic mechanisms.

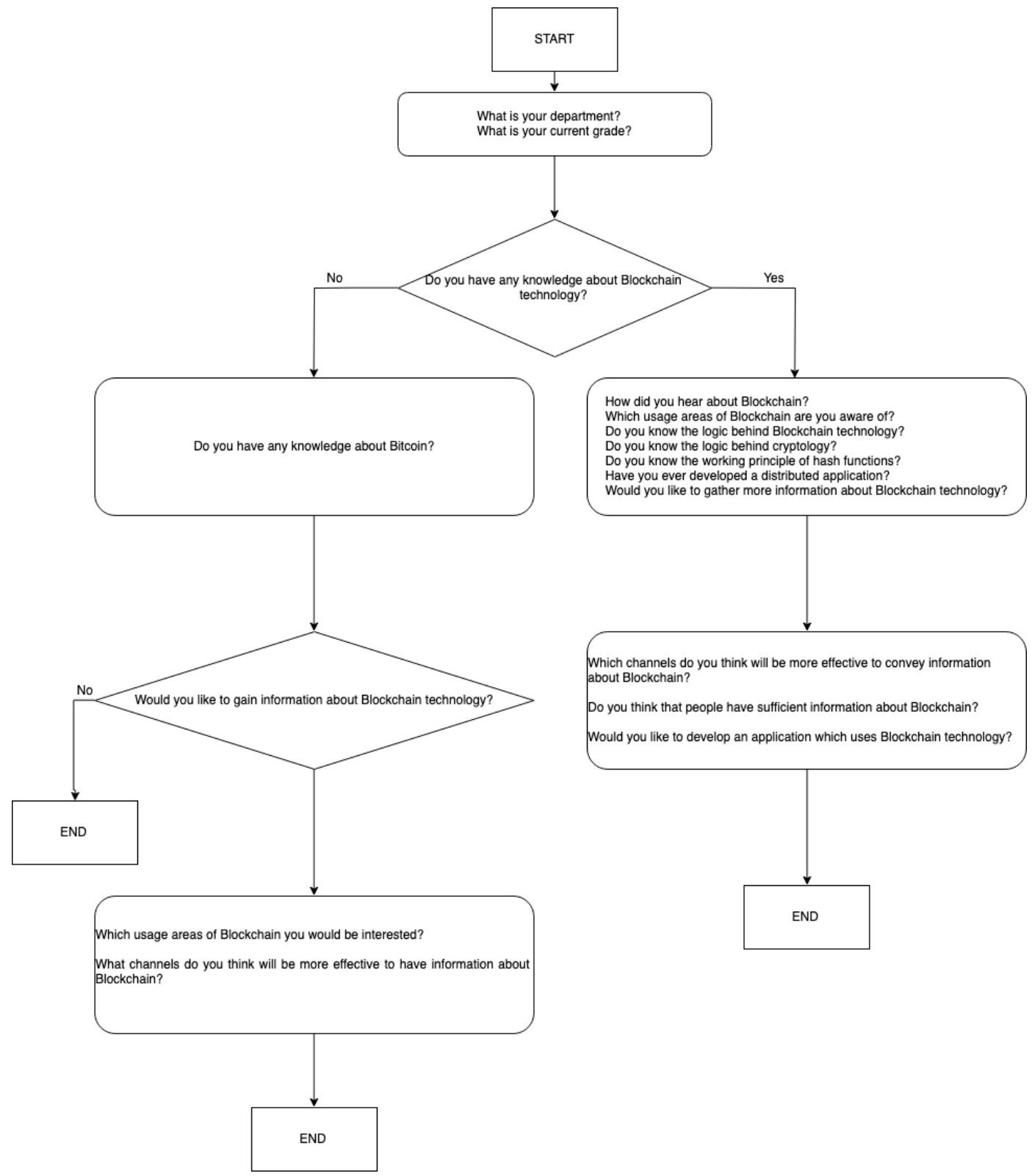

Figure 1. Algorithm of the questionnaire. 
The blockchain itself is a linked-list of blocks, where each block contains a hash value for previous block. The entire blockchain is accessible by all peers and they determine the current block on the network. Moreover, the approval process requires a complex computational task for public blockchains which use PoW like consensus algorithms (Nakamoto, S., 2008, Di Pierro, M., 2017). Briefly, the peers approve collectively the cur-rent block and the process moves on to the next block (Nakamoto, S., 2008, Cai, W., et al., 2018, Aste, T., et al.,.2017).

The blockchain network always stays transparent by being visible to all peers in the system. Therefore, understanding the principles of blockchain will ensure designers to extract advantages of blockchain technology on specific applications. Furthermore, it is significant to measure the awareness of designers about principles of blockchain since they will reveal the benefits of this technology to our society.

\subsection{Some Applications with Blockchain}

Companies invested around 1.4 billion USD on blockchain technology in 2016, which is a ten-fold increase from 2014 (Plarium., 2018). The investment trend and the expansion of blockchain technology into other fields is likely to continue in the future. Some current applications of blockchain include:

- Cryptocurrencies: Bitcoin (Nakamoto, S., 2008) being the pioneer of this field, blockchain networks allow secure transactions with digital currencies (Christidis, K. and Devetsikiotis, M., 2016).

- Gaming: Players and developers actively generate currency from games like Cryp-toKitties, due to them being blockchainbased games (Plarium., 2018).

- User Generated Content Networks (UCGN): Centralized UCGN are notorious in terms of keeping information about their users and there is a problem involving plagiarism in such networks with user content constantly being stolen. These prob-lems are candidates to be resolved with blockchain-based platforms such as STEEM (Cai, W. et al., 2018).

- Internet of Things (IoT): Smart contracts may be used to control some digital IoT devices with blockchain (Kshetri, N., 2017).

- Distributed File Stores: File stores utilize blockchain to offer for many services, such as providing high throughput (IPFS., 2018).

Since blockchain requires expertise from many technical areas, designers and de-velopers should be aware of principles about blockchain to be able to create a solve a challenge with this technology. University students may extend the state of the art about blockchain. Therefore, it is important to know the blockchain awareness of these students.

\section{A Questionnaire on Blockchain with University Students}

We have prepared an online questionnaire to assess the blockchain awareness of university students. The algorithm of the questionnaire is given in Figure 1.

\subsection{Demographics}

The participants of our questionnaire are 200 undergraduate students. We believe that current university students are among the best candidates to be developers and re-searchers related to blockchain technology. Thus, it has become a significant challenge to analyze their awareness (Mishra, M., 2018) and desire to contribute this technology.

Table 1. Distribution of Participants by Classes

\begin{tabular}{|c|c|}
\hline Class & Number of Students \\
\hline Preparatory & 11 \\
\hline Freshman & 46 \\
\hline Sophomore & 41 \\
\hline Junior & 23 \\
\hline Senior & 79 \\
\hline TOTAL & $\mathbf{2 0 0}$ \\
\hline
\end{tabular}

The largest group of participants are seniors that counts 79 out of 200 students. This indicates that seniors are more willing than other groups to respond to a ques-tionnaire about blockchain. Table 1 contains the distribution of participants to the questionnaire. 
Table 2. Distribution of Participants by Departments

\begin{tabular}{|c|c|}
\hline Department & Number of Students \\
\hline Computer Engineering & 40 \\
\hline Electronics \& Communications Eng. & 17 \\
\hline Industrial Engineering & 14 \\
\hline Economics & 10 \\
\hline Civil Engineering & 10 \\
\hline Architecture & 8 \\
\hline Others & 101 \\
\hline TOTAL & $\mathbf{2 0 0}$ \\
\hline
\end{tabular}

The largest group of participants are students from Computer Engineering depart-ments with 40 out of 200 students. This data may imply that Computer Engineering students are more willing to a questionnaire about blockchain than other groups. It may be related to the technical background of these students. Table 2 shows the distribution of participants according to their departments.

\subsection{Answers of Students about Blockchain}

We have prepared questions to extract the awareness of university students about blockchain technology. After determining departments and grades of students, we have started with a question to understand the general awareness of students about blockchain technology

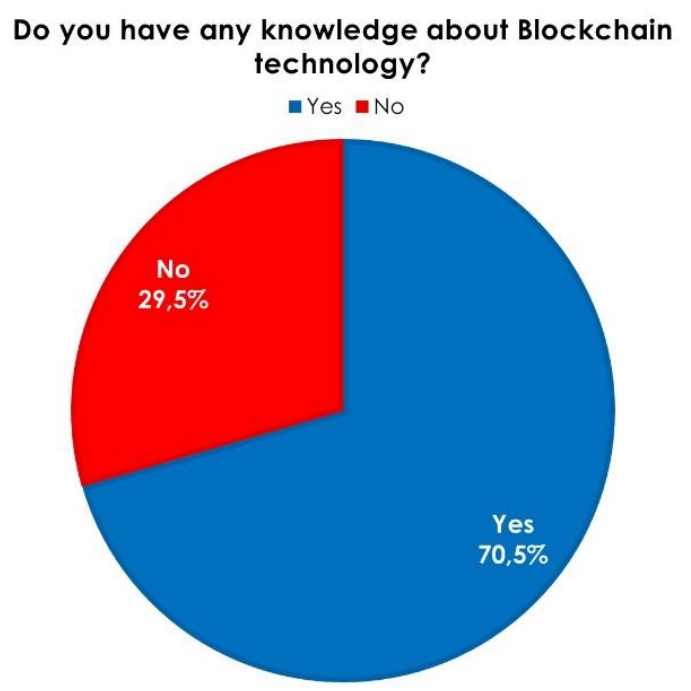

Figure 2. Blockchain awareness in general.

Fig. 2 shows results for this question. The results indicate that $70.5 \%$ of partici-pants are aware of blockchain, whereas $29.5 \%$ have no previous knowledge about the subject. The results show that a majority of university students are aware of blockchain while a large number of students still have no information about block-chain technology.

The next question depends on the answer given to the general awareness question. We have asked different questions to whom is aware of, Group A, and not aware of, Group B, blockchain technology. There are 141 and 59 participants from Group A and Group B respectively. 


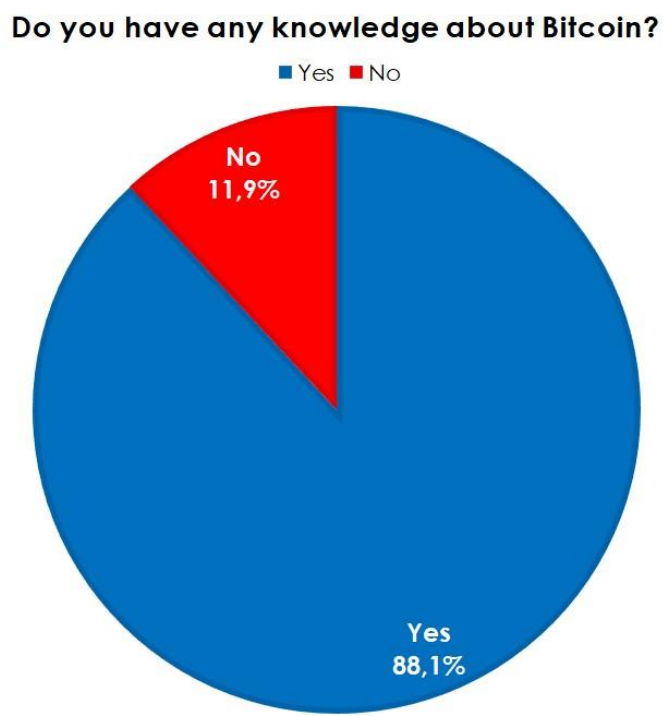

Figure 3. Awareness about Bitcoin.

One of the most well-known applications of blockchain is cryptocurrency, which has become popular with Bitcoin. There are students who do not know blockchain but they have information about Bitcoin. We have a question to test the awareness of Group B participants related to Bitcoin.

Figure 3 shows that many Group B participants are aware of Bitcoin but they do not know the technology behind the cryptocurrency. Specifically, $88.1 \%$ of Group B participants are aware of Bitcoin, whereas $11.9 \%$ of them has no previous infor-mation about this coin. These results reveal the fact that students have different in-terests on technology and its applications.

Willingness of the targeted audience is important to educate the people on a spe-cific subject. We have a question to Group B participants to be able to evaluate their willingness to learn something about blockchain technology. In Figure 4, we have pre-sented the results of willingness of Group B participants. 61\% of Group B participants would like to learn something about blockchain, whereas $39 \%$ of them have no inter-est in blockchain. These results show that most students who did not have knowledge about blockchain would like to learn the technology.

We proceeded with students who are interested in blockchain technology. The group, Group C, consists of 36 participants in total. We excluded other from the final questions of the branch.

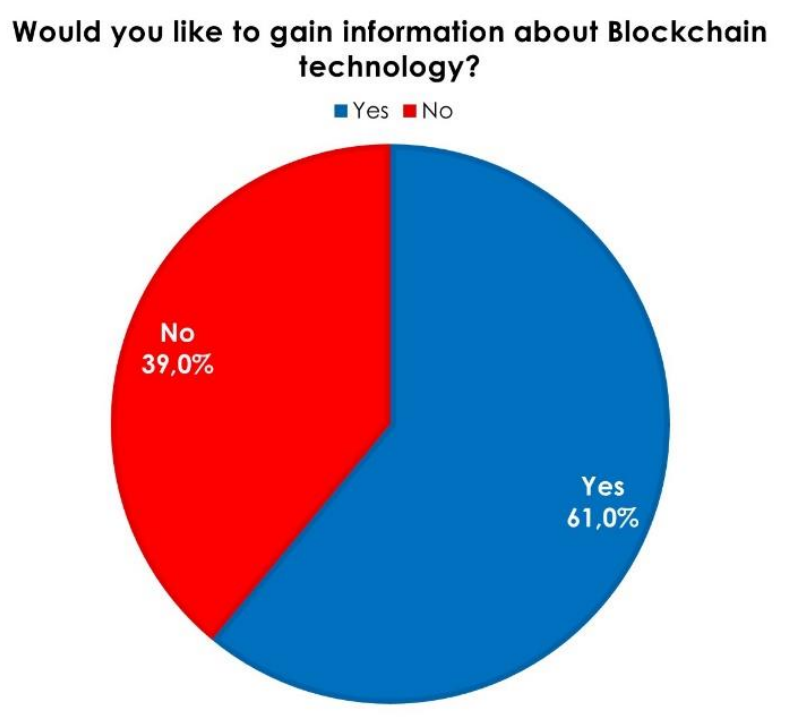

Figure 4. Willingness to know Blockchain.

Finding application areas that attract students may help to design better training programs for the students. Therefore, it is important to know which blockchain application area attracts students related to blockchain. In our questionnaire, we have devoted a question for this purpose. We asked a question to Group C students to select their preferred applications from a list of blockchain implementations. Cryptocurrency and information security are top areas that students want to work with blockchain technology as shown in Figure 5 . 


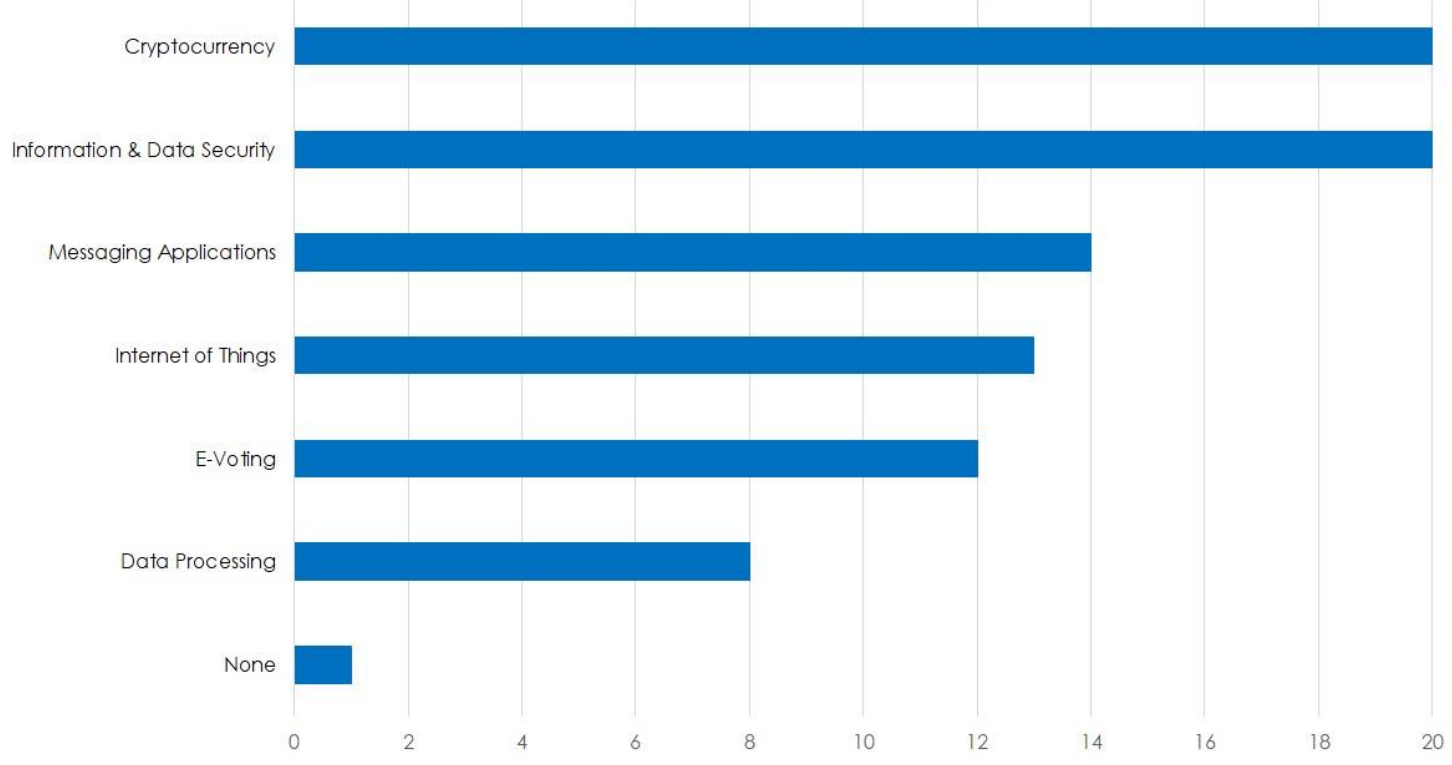

Figure 5. Blockchain areas of interest for Group C participants.

Students have many options to access information about specific topic. Most of the time, they prefer some channels instead of others. Preferred channels may in-crease the efficiency of training programs. Therefore, we asked students from Group $\mathrm{C}$ to reveal their desired channels to convey information about blockchain. We have found that web pages and visual materials (i.e. YouTube channels, videos) may be effective channels to reach the students about blockchain according to results in Figure 6.

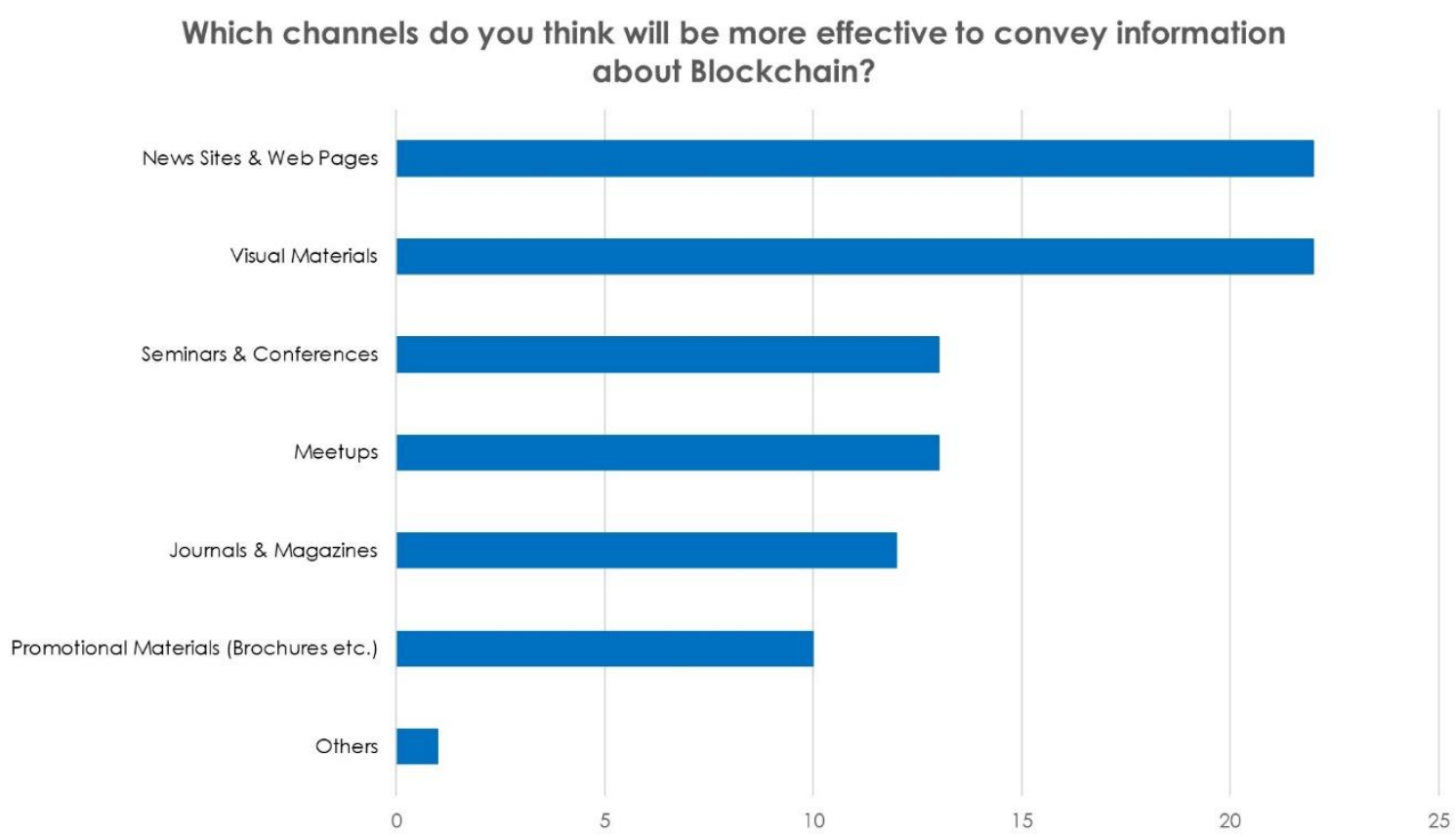

Figure 6. Preferred channels to learn blockchain by Group C participants.

We have investigated the channels from which students obtained information about blockchain with a question that we asked to Group A students. The goal of this question is to find the best channel to educate students about blockchain by reveal-ing existing channels that have been preferred by students from Group A. Answers of students from Group A shows that news sites and web pages have been the primary channel to reach information about blockchain as shown in Figure 7. Particularly, 119 and 66 students voted for news sites and web pages" respectively, which are the top counts. Moreover, these results are compatible with the most preferable channel of students from Group C. These results from Figure 7 and Figure 6 shows that the most ef-fective channel for Group C is the most known channel of Group A. Thus, training programs may consider news sites and web pages as the primary channels for blockchain trainings. 


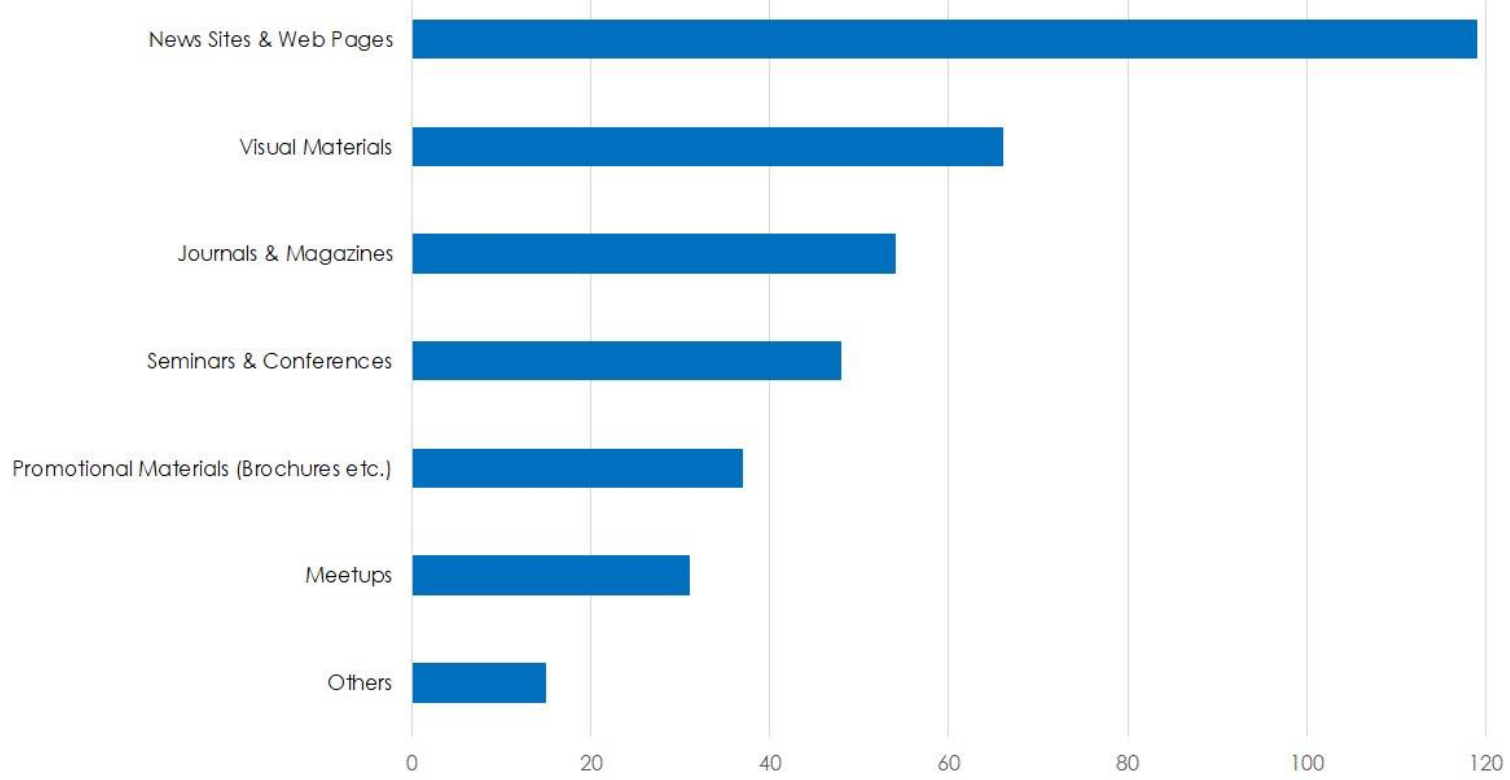

Figure 7. Channels of Group A participants to learn blockchain.

Similar to the previous question, we have investigated the application area aware-ness of blockchain with Group A students. Results show that cryptocurrency is the most known application area of blockchain by this group, where 137 out of 200 students know cryptocurrencies as shown in Figure 8. Results in Figure 8 and Figure 5 also indicate that students from both Group A and Group C know the relationship between cryptocurrency and blockchain. On the other hand, information security is still a widely known application area of blockchain but the awareness about other areas differ for these groups.

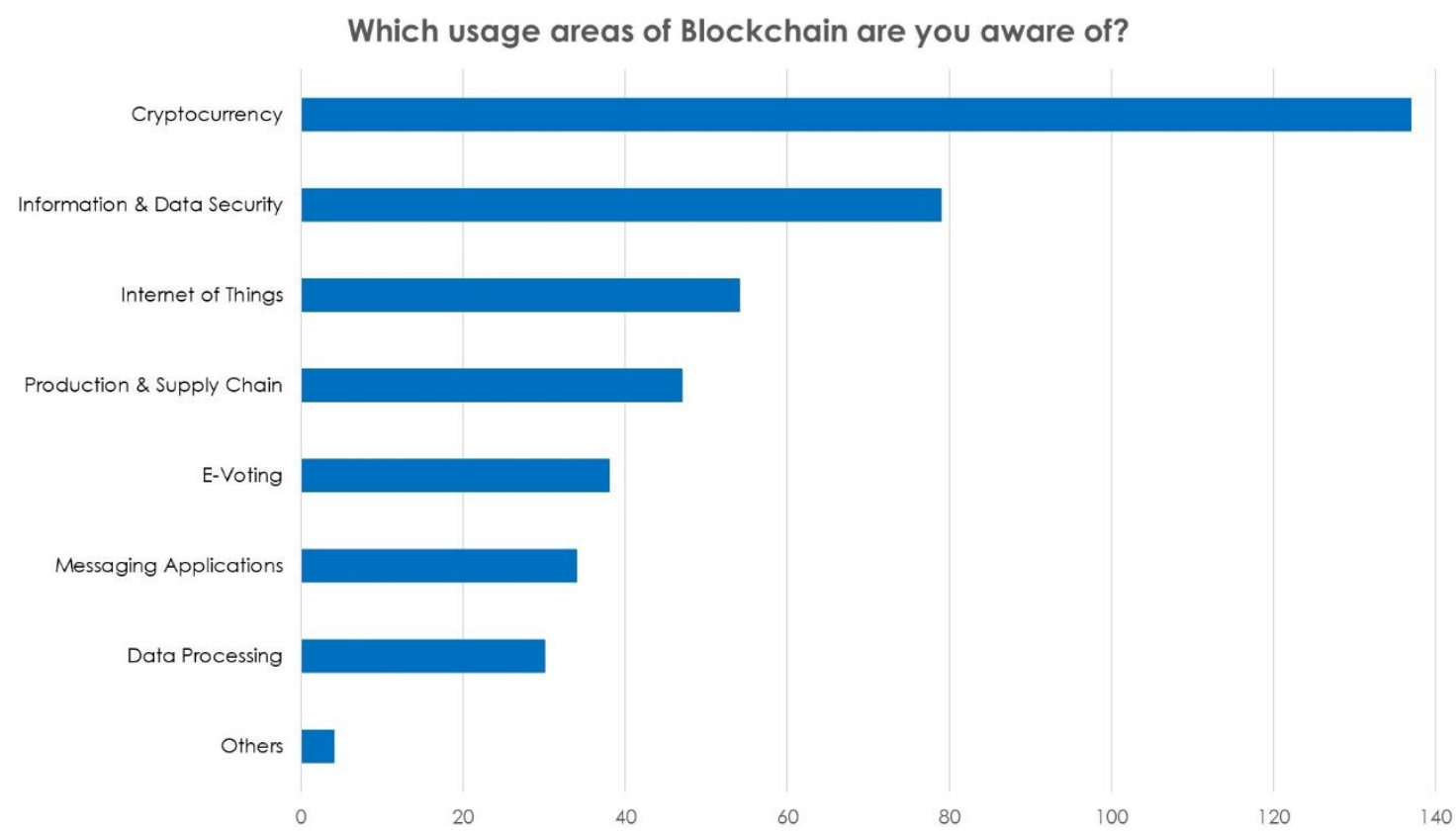

Figure 8. Awareness of Group A students about blockchain application areas.

We have more questions about details of blockchain. The goal of these questions is to reveal how many of the participants actually understand blockchain. For this reason, we have prepared three questions about the basic principles of this technology. The questions are about the logic behind blockchain, hash functions, and cryptog-raphy. Figure 9 shows answers given to these questions. Specifically, $63.1 \%$ of Group A participants know how blockchain works. Moreover, $66 \%$ of the same group participants indicates that they are aware of cryptology, and $45.4 \%$ of them know how hash functions work. These results show that less than $45.4 \%$ of Group A participants know how blockchain works. Since the majority of participants do not know the principle of blockchain technology, courses should start with fundamental mecha-nisms behind such technology. 

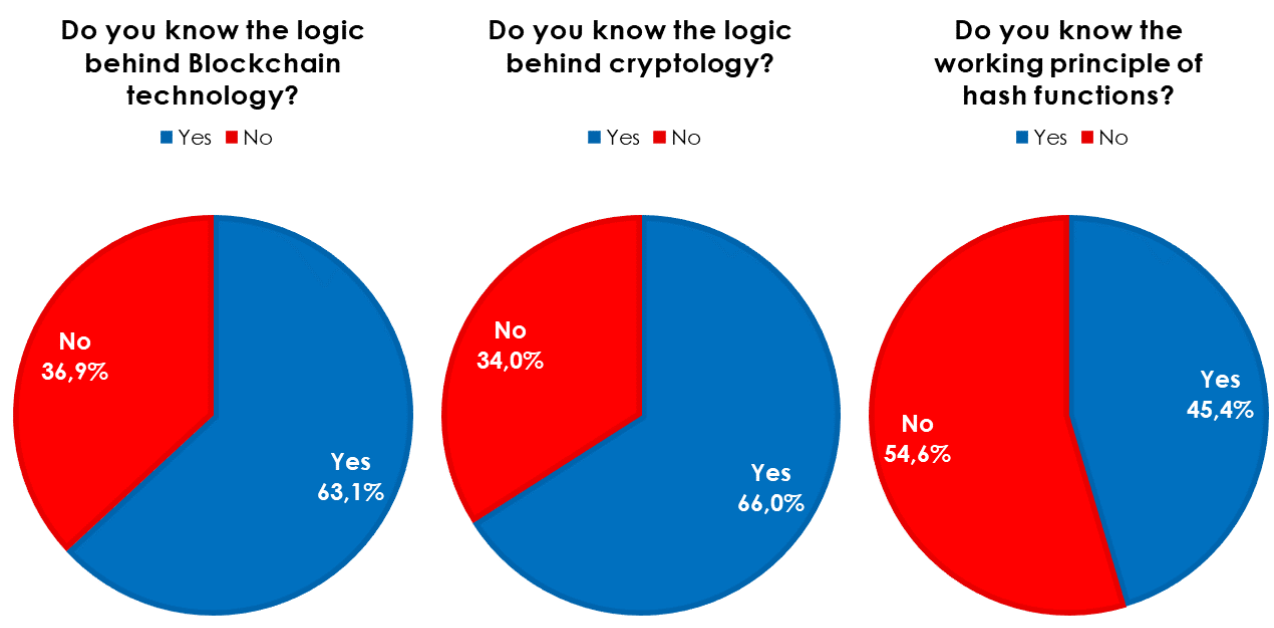

Figure 9. Some principles of Blockchain.

In order to understand current contribution of university students to blockchain technology, it is important to know to know how many of them are able to develop an application with blockchain. We have a question for Group A students about their experiences related to development of blockchain. Figure 10 contains results for Group A students, where 7.1\% of them said that they contributed to develop at least one blockchain application. While many students know principles of blockchain, only a small fraction of them has developed applications with blockchain.

One of the significant measures for trends about the number of researchers and developers related to a technology is the willingness of people to learn more information about the technology and become a contributor. In our questionnaire, we have two questions about this issue. Questions are used to assess interests of Group A students to learn more about blockchain and desire to develop an application in blockchain.

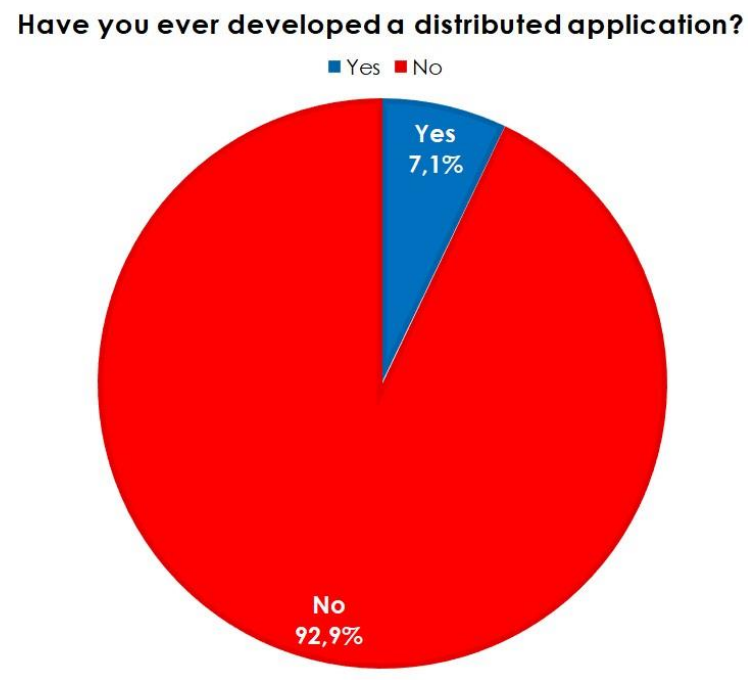

Figure 10. Blockchain developers.

Figure 11 contains willingness of Group A to more blockchain information and become a contributor. Particularly, 75.2\% of Group A would like to learn more on blockchain and $74.5 \%$ of them want to develop applications with blockchain. These results show that there is a huge interest on blockchain technology from university students. 

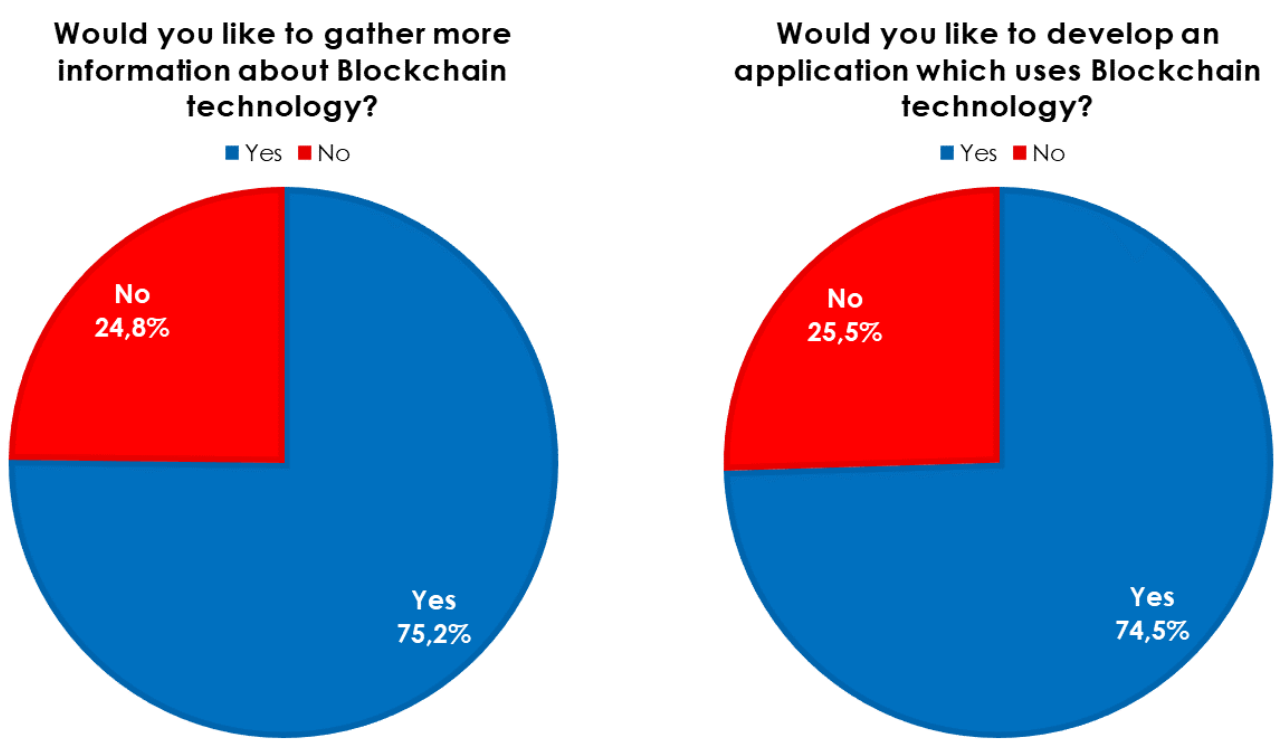

Figure 11. Willingness to contribute on Blockchain.

Our last question is about adequate sources about blockchain technology for Group A participants who want to have more information. We have defined anew group with these students, where there are 106 of them and we have asked an extra question regarding whether people were informed about blockchain sufficiently. Results in Figure 12 show that an overwhelming majority of these students believe that the society does not have enough sources and moreover people are unaware about blockchain technology. Specifically, only $6.1 \%$ of Group D participants believe that people have sufficient information about blockchain. These answers imply that blockchain is still thought to be a niche topic among university students.

The results show that university students are partially aware of blockchain and mechanisms behind this technology. On the other hand, the questions reveal that students are willing to know blockchain. Additionally, they want to contribute to the technology as a developer or a researcher. However, they believe that there is a lack of resources about trainings related to blockchain.

\section{Challenges}

During the survey, it has become apparent that some challenges exist to make block-chain helpful to the society. The first challenge is the fact people have no trust to unproven new technologies that are related to finance since there are many instances for mass frauds. Therefore, people have been suspicious about cryptocurrencies and blockchain.

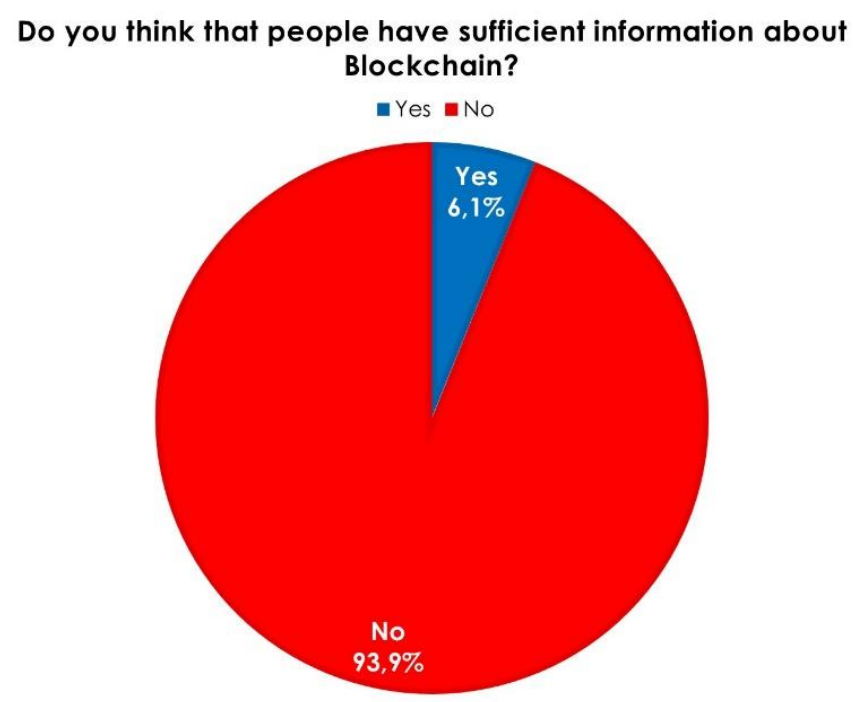

Figure 12. Adequate information sources for Blockchain.

Another challenge is a language barrier for educating people who are not native English speakers. Since most technical studies and sources about blockchain are in English, only students who know English have benefited from the most of existing resources. Additionally, the survey results reveal that students prefer visual resources such as YouTube, and these often do not convey in-depth 
information. For instance, the popularity of some the Internet resources may be a threat for people since they have no in-depth explanations of blockchain technology.

\section{Conclusions and Discussions}

Blockchain is going to be a cutting-edge technology when it becomes mature. University students are among the best candidates to contribute developing this technology. In this paper, we present a new questionnaire to extract the awareness of university students about blockchain and its application areas.

We conducted an online experiment with 200 university students. The experimental evaluation shows that the students are eager to contribute blockchain. However, they have no in-depth information about blockchain. Therefore, students need training and education programs to increase their knowledge. The experimental results show that students also prefer visual materials instead of written ones. Thus, results of the survey indicate that university students may contribute to blockchain research and development if there are adequate training and education programs.

There are several options to design a training or an education program related to blockchain. Content producers may offer appropriate training programs via the Internet. Technology foundations and associations may organize events such as seminars, conferences or summits about blockchain with the support of universities. In addition, these foundations and associations may support all people who have potential to develop applications with blockchain. Some departments of universities may offer courses about blockchain and its applications, such as in the department of computer engineering.

\section{References}

Nakamoto, S. (2008). Bitcoin: A Peer-to-Peer Electronic Cash System. Retrieved from https://bitcoin.org/bitcoin.pdf

Di Pierro, M. (2017). What Is the Blockchain?. Computing in Science \& Engineering, 19(5), 6-8

Yaksic, V.O.C. (2003). A study on hash functions for cryptography. Global Information Assurance Certification Paper, SANS Institute Roy, A. and Karforma, S. (2012). A survey on digital signatures and its applications. Journal of Computing and I.T., 3(1\&2), 46 - 69

Cai, W., Wang, Z., Ernst, J. B., Hong, Z., Feng, C. and Leung, V. C. M. (2018). Decentralized Applications: The BlockchainEmpowered Software System. IEEE Access, 6, 53019 - 53033

Aste, T., Tasca, P. and di Matteo, T. (2017) Blockchain Technologies: The Foreseeable Impact on Society and Industry. IEEE Computer, $50(9), 18-29$

Scriber, B. A. (2018). A Framework for Determining Blockchain Applicability. IEEE Software, 35(4), 70 - 77

Plarium. (2018). How Blockchain Games Can Change the Gaming Industry, Retrieved from https://plarium.com/en/blog/blockchaingames

Kshetri, N. (2017). Can Blockchain Strengthen the Internet of Things?. IT Professional, 19(4), 68 - 72

Christidis, K. and Devetsikiotis, M. (2016). Blockchains and Smart Contracts for the Internet of Things. IEEE Access, 4, 2292 - 2303

IPFS. (2018). Interplanetary File System, Retrieved from https://ipfs.io

Mishra, M. (2018). Bitcoin: A General Awareness Survey”, Journal of Business Management \& Quality Assurance, 2(1), 5 - 14

Henry, C., Huynh, K. and Nicholls, G. (2019). Bitcoin Awareness and Usage in Canada: An Update, Bank of Canada. Retrieved from https://www.bankofcanada.ca/2018/07/staff-analytical-note-2018-23/

Pawczuk, L., Massey, R., and Schatsky, D. (2018). Deloitte's 2018 Global Blockchain Survey. Retrieved from https://www2.deloitte.com/content/dam/Deloitte/us/Documents/financial-services/us-fsi-2018-global-blockchain-surveyreport.pdf

Deloitte's. (2018). Scotchain17 Blockchain Attitudes. Retrieved from https://www.mbnsolutions.com/wpcontent/themes/jobify/pdf/Scotchain17_Blockchain_SurveyWEB.pdf

Tanwar, S., Parekh, K., and Evans, R. (2020), Blockchain-based electronic healthcare record system for healthcare 4.0 applications, Journal of Information Security and Applications, 50, 102407

Dai, H., Zheng, Z., and Zhang, Y. (2019), Blockchain for Internet of Things: A Survey, IEEE Internet of Things Journal, 6(5), 80768094

Nosouhi, M., Yu, S., Zhou, W., Grobler, M., and Keshtiar, H. (2020), Blockchain for secure location verification, Journal of Parallel and Distributed Computing, 136, 40 - 51

Zheng, Y., Li, M., Lou, W., and Hou, Y.T. (2017), Location based handshake and private proximity test with location tags, IEEE Transactions on Dependable Secure Computing, 14, 406-419

Aggarwal, S., Chaudhary, R., Aujla, G. S., Kumar, N., Choo, K. R., and Zomaya, A. Y. (2019), Blockchain for smart communities: Applications, challenges and opportunities, Journal of Network and Computer Applications, 144, 13-48

Lo, S. K., Xu, X., Chiam, Y. K., and Lu, Q., (2017), Evaluating suitability of applying blockchain, In: IEEE 22nd International Conference on Engineering of Complex Computer Systems (ICECCS), 158-161 